\title{
Prevention of Congenital Malformations in the Offspring of Alloxan-diabetic Mice by the Insulin Treatment
}

\author{
Kin-ichi HORII \\ Department of Hygiene, University of Niigata School of Medicine \\ (Director : Prof. Gen-ichi Watanabe)
}

Unpedigreed virgin white mice of the Watanabe colony bred in this laboratory for a year and a half were used as experimental animals. Eighty $\mathrm{mg}$ of alloxan per $\mathrm{kg}$ body weight was given intravenously to the test group as well as the control on the 11 th day of gestation. The test group was treated 7 times with 0.4 units of "lente insulin" at 12-hour intervals from 36 hours after the alloxan injection, up to the 15th day of gestation. The dose of insulin incured no risk of hypoglycemia in diabetic mice, but was not necessarily enough to lower the elevated blood sugar levels to normal, in about half of all instances. Pregnant mice of both groups were sacrificed on the 19th day post coitum, and fetuses were removed by laparotomy and examined for externally visible defects.

No fetus with gross anomalies existed in 407 born to 40 successful pregnant mice in the test group. In the control group treated by alloxan alone, on the other hand, there were 9 pregnancies which had more than one malformed fetus out of 40 successful ones (22.5 per cent) and 25 fetuses with cleft palate out of 369 live-born (6.8 per cent). The term, "successful pregnancy", is regarded as a pregnant mother having more than one live fetus found at laparotomy on the 19th day of gestation.

An increase of the body weight due to pregnancy was less in mothers with malformed fetuses than in those with normal fetuses; this difference being statistically significant by means of the chi-square test with the probability level of 0.02 , whereas no appreciable difference was found between blood sugar levels in the two categories of mothers.

(pp. 988 995) 


\title{
糖尿病奇形の予防に関する実験的研究
}

\author{
新潟大学医学部衛生学教室 (指導 渡辺厳一教授) \\ 堀井欣一
}

(昭和38年 6 月 20 日受付)

緒 言

糖尿病の母親からは，しばしば奇形巟が生まれる ${ }^{1)}$.すなわち, Joslin Clinic の報告²によると，糖尿病の 母親から生まれた子供の $80 \%$ が奇形览であつたといら驚くべき事実がある. 最近 Driscoll ら ${ }^{33}$ は，糖尿病の 母汃らの生産児95例の死後剖検所見を記載し，20\%に外見上認めうる奇形があつたと報じている．糖尿病の 催奇形効果はひとり真性糖尿病にかざらない，Hoet ${ }^{4)}$ が，原因不明の奇形児を生んだき親の糖負荷血糖曲線 を調へたととろ，奇形临の $30 \%$ の親はそれが糖尿病前期状態、の範疇に入るものであつたという.

最近 Watanabe と Ingalls $\mathbf{s}^{5}$ は, 妊娠ハツカネズミをアロキサン糖尿病にかけ各種の奇形仔をえるととがで きた。 ての研究での特に重要な知見は妊娠の経過中アロキサンを投与する時期により, 現れる奇形の種類や 頻度が異なり，乙とに口蓋裂にあつて一定の法則をみいだしたてとである.

妊娠初期，いまだ形態形成の行なわれている時期に母親へ侮辱を与えると，奇形仔を生むという実験奇形 学的提示は多い6). しかし，乙れら侮辱に加うるに，それに対抗すべきなんらかの手段を講ずるてとにより， 奇形仔発生を予防しえた知見はいまだみることができない，実験的に奇形発生の予防ができるならば，それ は第 1 亿遺伝説と環境説の錯綜する奇形の原因論に有力な拋点を与えることになり，第 2 亿は予防医学上の 大きな笴与となるであろう.

著者は娃娠ハツカネズミにアロキサンを与えて糖尿病にし，さらにインシュリンを投与して，先天性奇形 発生の有様をみたのでこてに報告する。

\section{方法}

動物は実験動物中央研究所から入手し，さらに吾々の研究室で 1 年半飼育繁殖せしめた近交系処女ハッカ ネズミである.

予備実験としてアロキサン糖尿病ハツカネズミに対する“lente-insulin” の血糖低下作用を調べた．生後 12 週以上，体重 $25 \mathrm{gm}$. 以上の雄ハツカネズミ10匹䎲尾静脈よりアロキサン $80 \mathrm{mg} / \mathrm{kg}$. B. wt. を静注し, 糖尿 病をおてさせた．そして，24，36，48，72時間後の血煻変化を観察した。 ついで別群に同様アロキサン 80 $\mathrm{mg} / \mathrm{kg}$. B. wt. を静注，36時間後血糖を測定し直ちに “lente-insulin” を個体当り，それぞれ1.2，0.8， 0.6，0.4単位を12時間おきに皮下に注射し，かくして 4，8，12時間後の血糖を観察した．アアロキサンによ る過血糖の様子と，それに対抗すべき有効インシュリン量を決定したのち本実験を行なつた。

まず, 生後 12 週以上, 体重 $25 \mathrm{gm}$. 以上の処女ハッカネズミを同系の雄と交配せしめ, 毎朝交尾栓を調べた. そして，もしてれをみたならば妊娠第 1 日目とし，11日目にアロキサン $80 \mathrm{mg} / \mathrm{kg}$. B. wt. を静注した。 そ の36時間後より12時間毎に 7 回，すなわ515日目の夜まで “lente-insulin” 0.4 単位を皮下注射した。 ての群 を実験群, 同様の要領でアロキサンのみを投与した群を対照群とした，不妊子宮，死亡例があつたため，両 群とも成功妊娠 (19日目の開腹で，1 匹以上生存胎仔をみたものをいう）40例をうるに，前者で59匹，後者 で76匹を要した.

実験群ではアロキサン注射36時間後, おょび第 2 回目 “lente-insulin” 注射 4 時間後, また対照群ではア ロキサン注射 36 時間後, それぞれ血糖值を測定した。乙の間妊娠第 1 日，11日，15日，19日目に全動物の体 重計測を行なつた. 
母親が出産した奇形仔を食い殺すととを予防するために，出産予定の前日，すなわち，妊娠第19日目に開 腹して胎仔をとりだし，外見的奇形の有無を検した。

血糖測定は尾末端より $0.05 \mathrm{ml}$ 血糖測定用ピペットで採血し, Somogyi-Nelsonの微量法》を用いて行なつ た.

アロキサンは注射直前，そのつど $2.0 \%$ 水溶液を作り使用した。 インシュリンは米国 Eli Lilly 社製 “lente-insulin”を注射直前蒸溜水で 4 倍に稀勫して用いた。

骨奇形の検査はつぎの要領で行なつた。肉眼的奇形観察の後, $70 \%$ アルコール漬けにした胎仔が十分硬化 するをまつて内藏を除去し，1\% $\mathrm{KOH}$ 溶液中に入れる。24時間後，骨格が透視できるようになつてから，

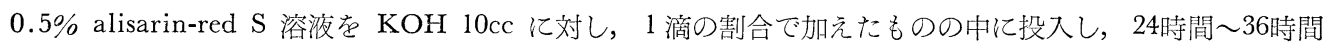
染色後水洗観察した.

結 果

血糖値の観察 :

アロキサン $80 \mathrm{mg} / \mathrm{kg}$. B. wt. 注射後の血糖変化は Fig. 1 亿示すとおりである. 投与後 36時間で血糖值は 頂上に達し, 以後てれを持続した。 標本平均值を中心としての斜線部分は母集団平均値 $95 \%$ の信頼限界を示 すものである.

Fig. 1. Change of the Blood Sugar Level in Mice After Intravenous Injection of Alloxan (80mg per kg. B. Wt.).

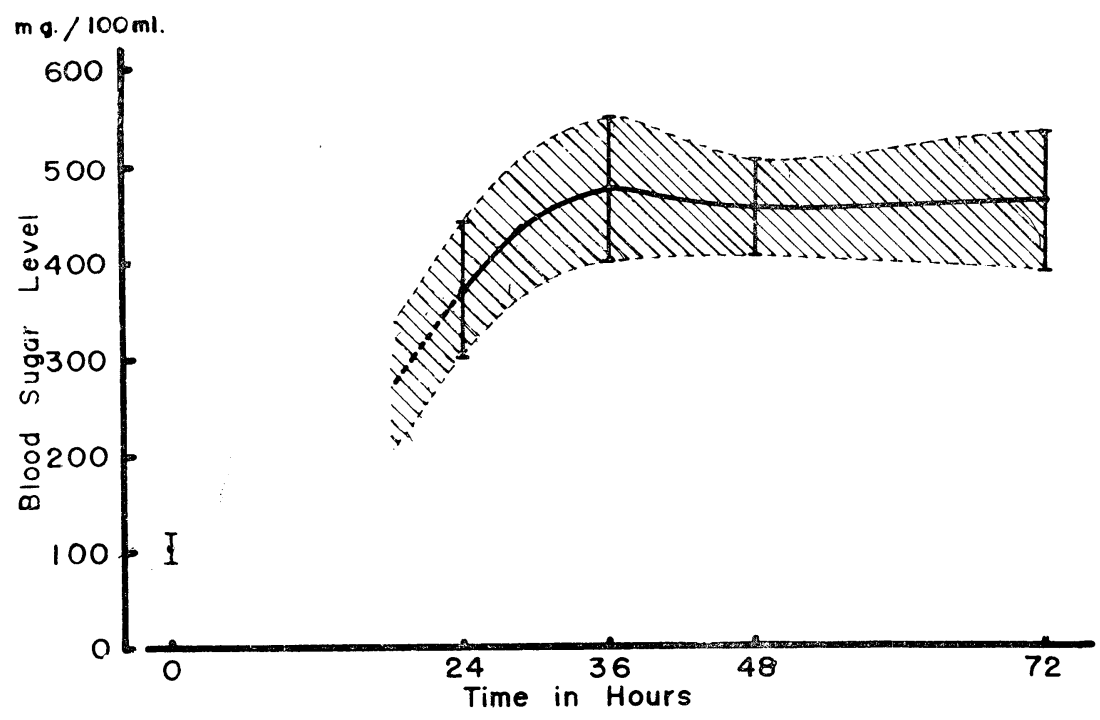

Fig. 2. はアロキサン過血糖に対する0.4 1.2単位/個体のインシュリン投与による血糖変化の模様を示した ものである．アロキサン投与36時間後の血糖值 $95 \%$ 信頼限界の幅は, $325 \pm 122 \mathrm{mg} / 100 \mathrm{ml}$ であつた. “lenteinsulin” 注射の血糖値におよぼす効果はつぎのとおりである。第 2 回目 1.2 単位/個体を注射し，4，8， 12時間後の平均血糖值の変化をみると, それぞれ $86 \pm 70 \mathrm{mg} / 100 \mathrm{ml}, \quad 317 \pm 127 \mathrm{mg} / 100 \mathrm{ml} ., \quad 393 \pm 136 \mathrm{mg} /$ $100 \mathrm{ml}$. であつた. 4 時間後の血糖值で， $50 \mathrm{mg} / 100 \mathrm{ml}$. 以下を示すものが 10 例中 5 例あり, うち 1 例は死亡 した. ついで第 4 回目のインシュリン注射, 0.8 単位/個体の場合には 4 時間後が $166 \pm 99 \mathrm{mg} / 100 \mathrm{ml}$ であつ た. 乙の場合も 9 例中 $50 \mathrm{mg} / 100 \mathrm{ml}$ 前後のものが 3 例あり, 低血糖を生ずる危険がある. 第 6 回インシュリ ン注射で 0.4 単位/個体を使用した場合， 4 時間後の $95 \%$ 信頼限界の幅は $195 \pm 76 \mathrm{mg} / 100 \mathrm{ml}$ であり，最低 98 
$\mathrm{mg} / 100 \mathrm{ml}$ ，最高 $354 \mathrm{mg} / 100 \mathrm{ml}$ であつた。 Fig. 2 で興味あるてとは，インシュリン注射の効果が消失した 後に示す高血糖はインシュリン投与毎に次第に上昇するととである. ての間, アロキサン過血糖とインシュ リンによる血糖低下の間には認むべき関連がなかつた。これは血糖值の高低よりむしろインシュリン感受性 の個体差にもとづくものかもしれない．

Fig. 2. Effect of Insulin Treatment against Alloxan Hyperglycemia

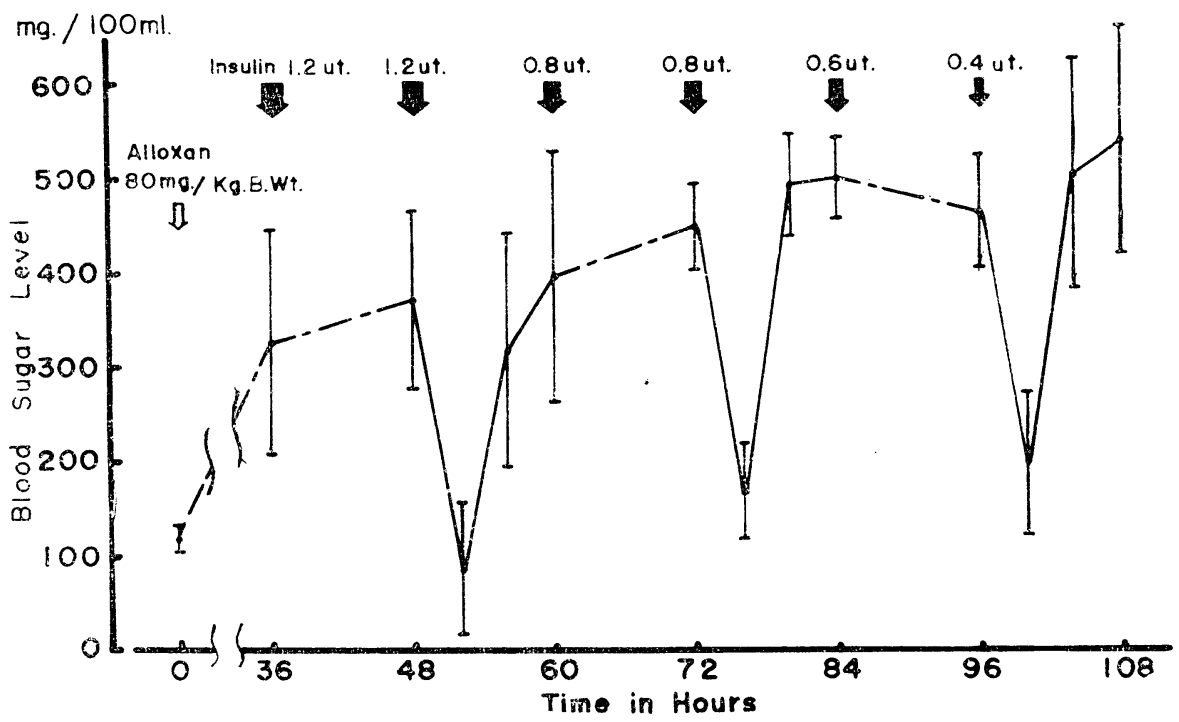

以上の血糖観察から案ずるに，アロキサン $80 \mathrm{mg} / \mathrm{kg}$. B. wt. 静注による糖尿病に対して，インシュリン $0.4 \sim 0.5$ 単位/個体が本実験の目的に沿うと判断される.

奇形の観察 :

血糖值ならびに体重の変化は Table 1 亿まとめてある，妊娠11日目にアロキサンを投与し，40例36時間 後の $95 \%$ 信頼限界の幅は, 実験群 $540 \pm 82 \mathrm{mg} / 100 \mathrm{ml}$, 対照群 $506 \pm 62 \mathrm{mg} / 100 \mathrm{ml}$ であつた。 また，前者のイ ンシュリン投与 4 時間後のそれは $222 \pm 54 \mathrm{mg} / 100 \mathrm{ml}$ で，最低值は $75 \mathrm{mg} / 100 \mathrm{ml}$ ，最高值は $390 \mathrm{mg} / 100 \mathrm{ml}$ で あつた。

Table 1. Comparison of Blood Sugar Levels and Body Weights of Insulin-injected with -noninjected Groups of Alloxandiabetic Pregnant Mice

\begin{tabular}{|c|c|c|c|c|c|c|c|}
\hline & \multirow{2}{*}{$\begin{array}{l}\text { No. of } \\
\text { Successful } \\
\text { Pregnancies }\end{array}$} & \multicolumn{2}{|c|}{$\begin{array}{l}\text { Blood Sugar Levels } \\
\quad(\mathrm{mg} / 100 \mathrm{ml})\end{array}$} & \multicolumn{4}{|c|}{$\begin{array}{l}\text { Body Weight Change during } \\
\text { Pregnancy (gr) }\end{array}$} \\
\hline & & $\begin{array}{l}\text { 36hrs. after } \\
\text { All. Inj. }\end{array}$ & $\begin{array}{l}4 \text { hrs. after } \\
\text { Ins. Inj. }\end{array}$ & 1st Day & $\begin{array}{l}11 \text { th } \\
\text { Day }\end{array}$ & $\begin{array}{l}15 \text { th } \\
\text { Day }\end{array}$ & $\begin{array}{l}19 \text { th } \\
\text { Day }\end{array}$ \\
\hline $\begin{array}{l}\text { Alloxan- } \\
\text { Insulin } \\
\text { Group }\end{array}$ & 40 & $540 \pm 82$ & $222 \pm 54$ & 25.1 & 29.4 & $31.9 \pm 2.2$ & $35.9 \pm 3.8$ \\
\hline $\begin{array}{l}\text { Alloxan } \\
\text { Group }\end{array}$ & 40 & $505 \pm 62$ & & 24.8 & 29.1 & $28.5 \pm 2.2$ & $33.5 \pm 3.8$ \\
\hline \multicolumn{2}{|c|}{ Significance } & & $\mathrm{P}<0.01$ & $\mathrm{P}>0.05$ \\
\hline
\end{tabular}


これら両群間の体重の変化はアロキサン投与後, 契験群（アロキサンーインシュリン注射群）では, 体重 増加があり，対照群（アロキ+ン注射群）では，体重増加が少なかつた。

なお15日目の両群の体重を，それぞれの11日目の体重に比較した増加率の差は有意であつた $(\mathrm{P}<0.01)$.

胎仔に発生した奇形の種類と頻度は Table 2 に示すとおりである. 実験群では40例の母親からの胎仔数

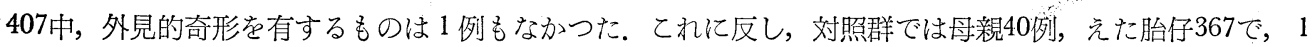
仔以上奇形仔をもつ寿親 $9(22.5 \%)$, 胎仔数では $25(6.8 \%)$ に口蓋裂をみた. ての場合, 他の外見的奇形 はみられなかつた。

Table 2. Comparison of Frequencies of Congenital Malformations between Insulin-injected and -noninjected Groups of Alloxan-diabetic Pregnant Mice

\begin{tabular}{|c|c|c|c|c|c|c|c|c|c|}
\hline & \multirow{3}{*}{$\begin{array}{l}\quad \text { No. of } \\
\text { Successful } \\
\text { Pregnancies }\end{array}$} & \multirow{3}{*}{$\begin{array}{l}\text { No. of } \\
\text { Fetuses } \\
\text { (Average } \\
\text { Size of } \\
\text { Litter) }\end{array}$} & \multicolumn{2}{|c|}{ Cleft Palate } & \multicolumn{5}{|c|}{ Rib Abnormalities } \\
\hline & & & \multirow{2}{*}{$\begin{array}{l}\text { No. \&Percent } \\
\text { of Mothers } \\
\text { with Malformed } \\
\text { Fetuses }\end{array}$} & \multirow{2}{*}{$\begin{array}{l}\text { No. \& Percent } \\
\text { of Malformed } \\
\text { Fetuses }\end{array}$} & \multicolumn{4}{|c|}{$\begin{array}{l}\text { Frequency } \& \\
\text { Percent of } 14 \text { Ribs }\end{array}$} & \multirow[t]{2}{*}{$\begin{array}{l}\text { Wavy } \\
\text { Ribs }\end{array}$} \\
\hline & & & & & total & r. & 1. & both & \\
\hline $\begin{array}{l}\text { Alloxan- } \\
\text { Insulin } \\
\text { Group }\end{array}$ & 40 & $\begin{array}{c}407 \\
(10.2) \\
\end{array}$ & 0 & 0 & $\begin{array}{c}150 \\
(36.9 \%)\end{array}$ & 23 & 49 & 78 & 0 \\
\hline $\begin{array}{l}\text { Alloxan } \\
\text { Group }\end{array}$ & 40 & $\begin{array}{c}367 \\
(9.2)\end{array}$ & $\begin{array}{c}9 \\
(22.5 \%)\end{array}$ & $\begin{array}{c}25 \\
(6.8 \%) \\
\end{array}$ & $\begin{array}{c}139 \\
(37.8 \%) \\
\end{array}$ & 21 & 52 & 66 & 1 \\
\hline
\end{tabular}

Fig. 3. Body Weight Changes from 11th to 15th Days of Pregnancy in Alloxan-diabetic Mice with and without Malformed Fetuses.

Difference between both groups is statistically signigcant with the probability level of less than 0.02 .
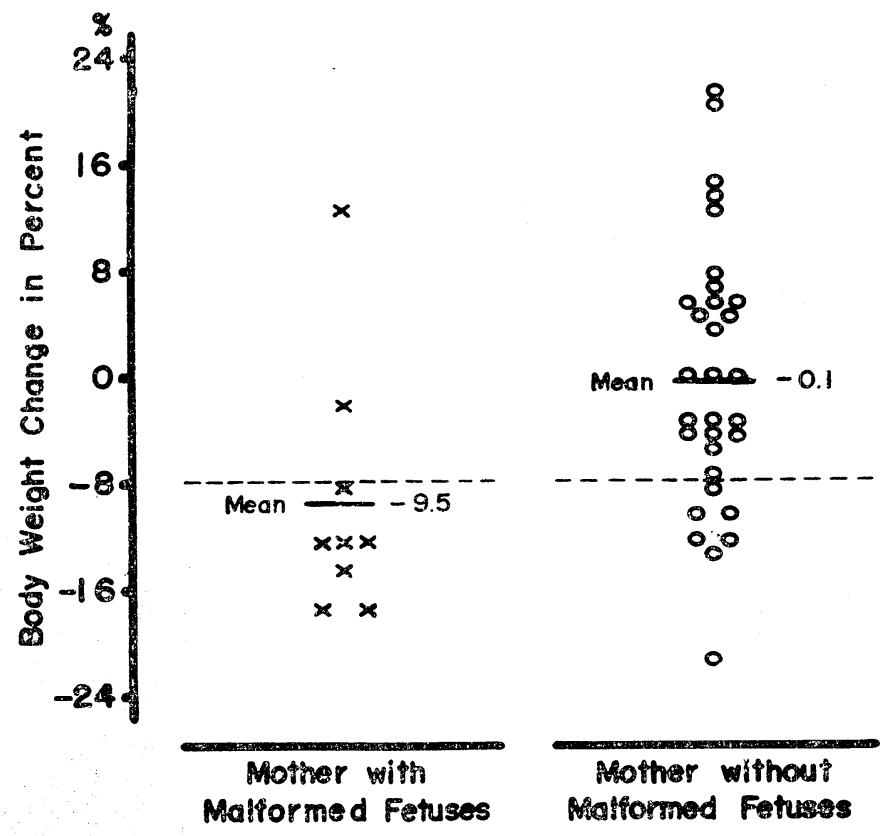
Photograph 1. Normal palate of nineteen-dayold pregnancy.

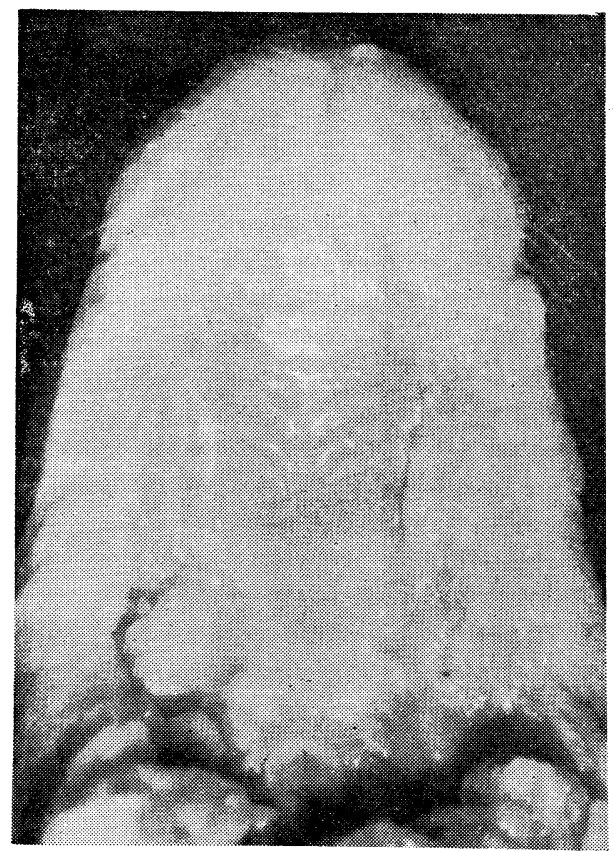

Photograph 3. Cleft palate of the second grade after alloxan treatment on the 11th day of gestation.

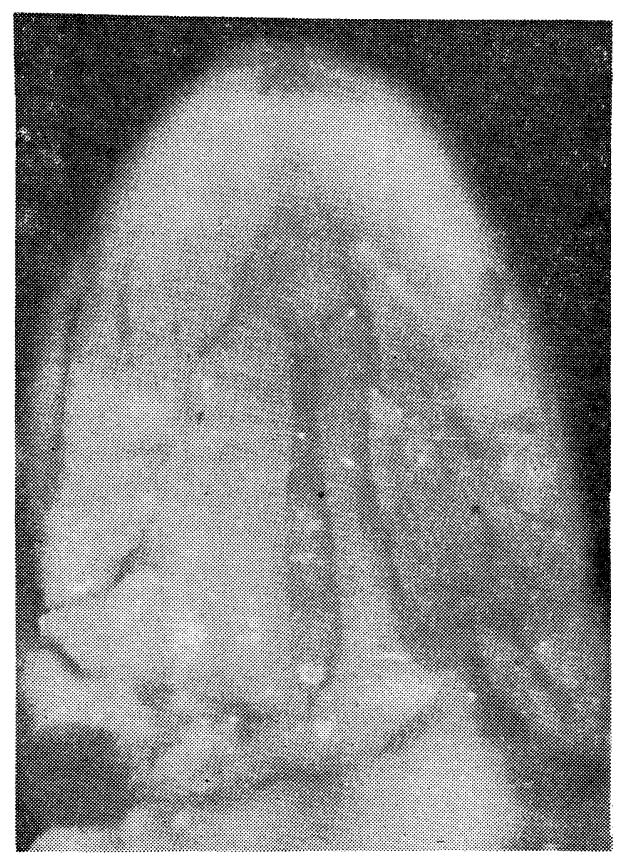

Photograph 2. Gleft plate of the first grade after alloxan treatment on the 11 th day of gestation.

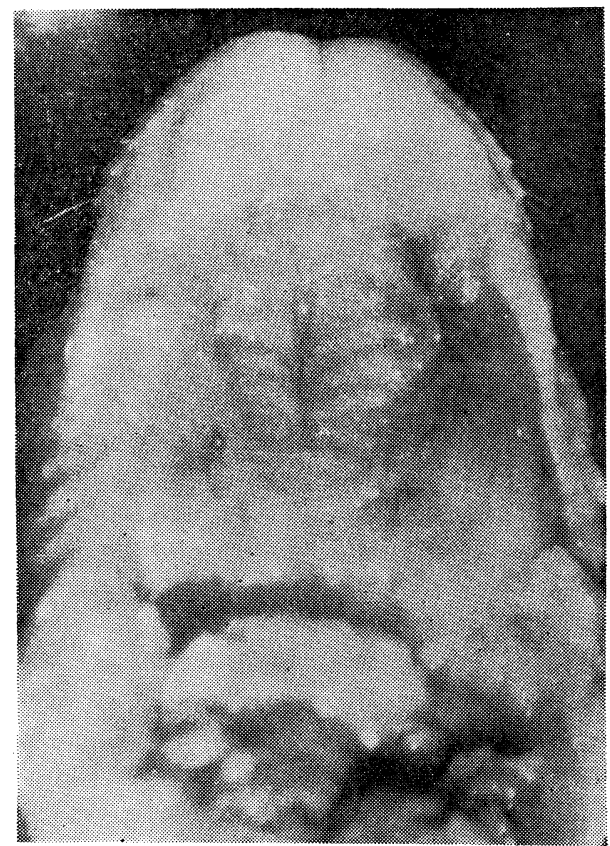

Photograph 4. Cleft palate of the third grade after alloxan treatment on the 11th day of gestation.

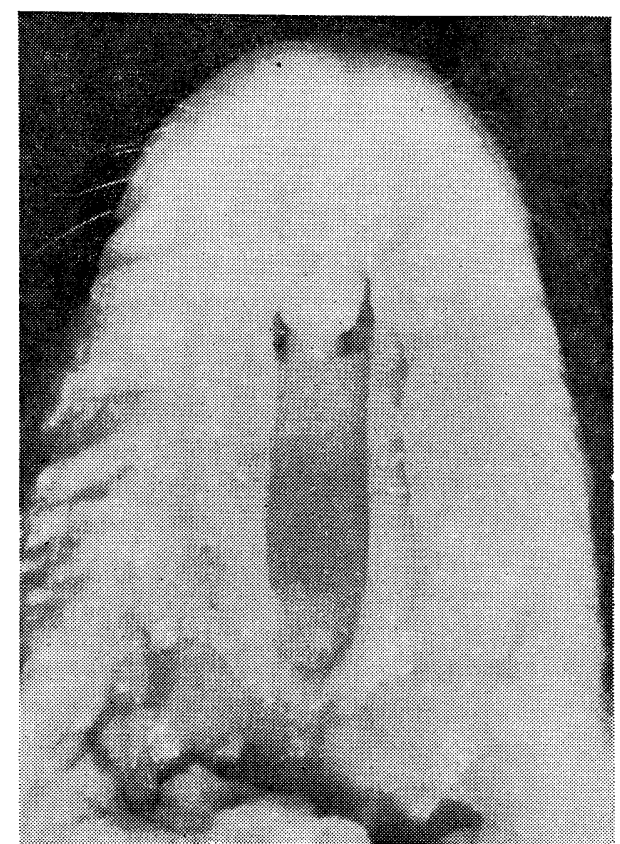


アロキサン注射群において高血糖の多寡と口盍裂発生との間には, 格別の相関をみなかつた。一方, 妊娠 11日目アロキサン静注直前の母ネズミの体重に対し，妊娠15日目（アロキサン一インシュリン注射群では， 7 回の注射を終了した直後に相当する）の体重増減の分布を示すと，Fig. 3 のとおりである.すなわちこの 図から妊娠による体重増加がないのみならず，むしろ減少度の強い母ネズミにロ蓋裂胎仔発生頻度の高いこ とを知る。いま体重 $8 \%$ 減を界とし， $x^{2}$-test を行なうに，0.02以下の危険率で上記傾向は有意であつた。 写 真 1 〜 はそれぞれ本実験でえた正常口蓋，軽度口蓋裂，中等度口蓋裂，高度口蓋裂を示す.

骨異常に関し14本肋骨をもつものの出現頻度は, 実験群, 対照群ほぼ同様であつた。 ただし, 対照群に波 状肋骨 1 例があつたほか, 骨異常に特記すべきものはなかつた。

実験群で全母親59匹中，不妊子宮10匹 (17.0\%), 死亡 9 匹 (15.3\%), 対照群では全母親76匹中，不妊子 宮 7 匹 $(9.2 \%)$, 死亡29匹 $(38.2 \%)$ があつた. 死亡例は前者で開腹前 $2 \sim 3$ 日が多く，後者ではアロキサ ン投与 $4 \sim 5$ 日目から開腹前までほぼ等しく散在していた。 なお，念のため開腹直前に死亡した例について 胎仔奇形を調べたとてろ，前者で母親 2 匹中，奇形胎仔はみられず，後者で母親 4 匹，えた胎仔 33 中，奇形 仔 1 匹以上もつ母親 3 匹および15胎仔に口蓋裂をみた.

\section{考案}

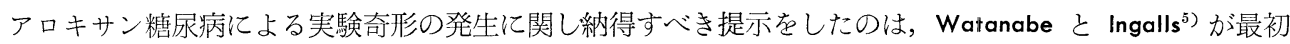
である. 彼らはハツカネズミの妊娠 $9 \sim 14$ 日目に $100 \mathrm{mg} / \mathrm{kg}$. B. wt. のアロキサンを静注し，四肢奇形，口 蓋裂，骨格奇形などをえている。乙のうち注射日と口蓋裂発生頻度との間には注目すべき関係があつた。す なわち成功妊娠15例中，妊娠 9 ～11日にアロキサンを注射した群では30〜45\%が1 仔以上口蓋裂をもつ胎仔 を有し，以後漸減し14日目注射群ではすでに口蓋裂仔をえるてとができなかつたという．

さきに Ingalls とその共同研究者 ${ }^{8}$ は，妊娠 2 日目から18日目までのハツカネズミを各々 1 回 5 分間ずつ, それぞれ無酸素状態におき19日目に開腹して，生存胎仔を調べたところ，15日目に無酸素侮辱を与えたもの にロ蓋裂が多発したと報じている。

さらに Ingalls9 は，妊娠10日目から15日目までの母ネズミに hydrocortisone を与えている。乙の際口蓋 裂の頻度は妊娠13日目に侮辱を与えた群に最く多く出現した。

このようにして胎仔に口蓋裂を発生せしめるためには，母へ与える侮辱の種類により臨界時が異なる，無 酸素刺激は催奇形効果が一過性であり，hydrocortisone はそれよりやや長く，アロキサンの効果はさらに慢 性，かつ蓄積的であるといえよう。ちなみにハツカネズミの口蓋閉鎖時期は株により多少異なるが妊娠16日 目といわれている10).

一方インシュリンに催奇形効果のあることは早くから判つていた．すなわち Duraiswami ${ }^{11)}$ は粰化中の鶏

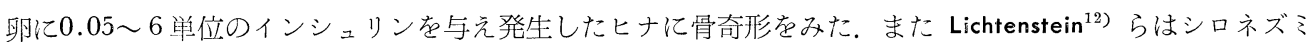
に“protamine-zinc-insulin” 1 回 7〜8 単位を注射し同様骨奇形をえたと記載している. Ingalls ${ }^{13)}$ は，妊 娠 8 10日目のハツカネズミにインシュリンを投与したとてろ, 頭蓋破裂，骨格奇形をもつ胎仔をえている. これら実験的奇形発生に対し，ヒトへのインシュリン投与が胎児へ奇形を誘発するという記載がある. Wickes $\left.{ }^{14}\right)$ は，妊娠 8 週以前の精神分裂症患者に insulin-shock 療法を施したところ奇形児が生まれたと誌し ている.

以上の事実からアロキサンとインシュリンの両催奇剤を併用する場合，それぞれ投与の時期と量に対し慎 重な注意が払われねばならぬととを知る。

本実験での血糖值はアロキサン投与36時間後おおむね頂上に達した．乙れはさきに行なつた Watanabe

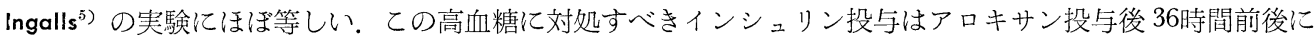
開始されねばならない，乙こに用いた “lente-insulin”は，速効性と緩効性の混合インシュリンである，七 トに適用する場合高血糖抑制効果は24〜30時間持続するといわれる ${ }^{15)}$. しかるにハツカネズミではFig. 2に 示すとおり効果の持続時間短く，血糖值は注射後12時間にしてすでに注射前の高血糖にもどつてしまう.し 
たがつてこの研究では，胎仔口蓋閉鎖が終了するまで受胎後12日から12時間ごとに 7 回インシュリンを投与 したのである。乙の間インシュリン低血糖を生ずるような量はそれ自体が催奇形効果を発するので好ましく ない.すなわち，乙とでは，高血糖を十分抑えるインシュリン量というよりは，むしろ低血糖をおてす危険 のないインシュリン量を決めてそれを使用したのである。それが0.4単位/個体であつた．結果はすでに述べ たように蘚かなものである、インシュリン投与群にあつては1例の奇形仔もえるてとはなかつたが，非投与 群では生存胎仔367中25の口蓋裂胎仔をえたのである.

Lukens ${ }^{16)}$ はアロキサンには “histotoxic”な作用と“diabetogenic” な作用があると云つた. このどちら に催奇形效果があるかを判断するのは困難である. Watanabe と Ingalls ${ }^{5}$ ) はアロキサンの催奇形効果が前述 のように持続的蓄積的であるところから “diabetogenic”な効果に催奇形作用があると思案している。本実 験の結果からみて Watanabe と Ingalls s) $^{5}$ 考光方注正しいように思わ机る。それはインシュリンに抗アロ キサン細胞毒效果があるとは思えないからである.

この実験で用いたインシュリン量は前述のように高血糖を抑えるに必ずしも十分ではなかつた。インシュ リン投与 4 時間後 $300 \mathrm{mg} / 100 \mathrm{ml}$ 以上の高血糖を示す例があつた，それにもかかわらず奇形仔は出現しなか つた，さきに Watanabe らが高血糖と奇形仔発生に格別の相関をみとめなかつたてと，そして高血糖のな い゙糖尿病前期状態、の母親から奇形巟が生まれる疫学的事実などを勘案し，上述のととは納得ができるよう に思われる。糖尿病の催奇形効果は高血糖それ自体よりはむしろ母体の広範な代謝性 homeostasis の失調 に基因するものであろう。アロキサン糖尿病の重症度，ひいて催奇形強度は高血糖よりむしろ妊娠による体 重増加のより少ないという点に相関か漒かつたからである.

\section{結 論}

妊娠ハツカネズミをアロキサン糖尿病にかけさらにインシュリンを投与して先天性奇形の出現頻度を非イ ンシュリン投与群と比較した。

アロキサン $80 \mathrm{mg} / \mathrm{kg}$. B. wt. 静注しておてる過血糖に対抗し，低血糖をおこす危険のない “lente-insulin” 量は0.4〜0.6単位/個体であつた.

妊娠11日目の動物にアロキサン $80 \mathrm{mg} / \mathrm{kg}$. B. wt. を静注し，36時間後から12時間ごとに7回，“lenteinsulin” 0.4単位皮下注射をした，妊娠19日目に開腹し胎仔を取出し外見的奇形と骨奇形の観察を行なつた.

インシュリン投与群の成功妊娠例（19日目開腹時，1 仔以上の生存胎仔をもつもの）にあつてえた胎仔数 407中，1例の奇形仔もみることはなかつた。これに反し非インシュリン投与群では母ネズミ40，えた胎仔 367 , 中奇形仔をもつ母親は 9 匹 $(22.5 \%)$, 胎仔数 $25(6.8 \%)$ に口蓋裂をみた.

これら奇形仔をもつ母親はしからざる母親に比べ，血糖值に格別の特徴はなかつたけれども弤娠による体 重増加率が極めて低かつた。

打わりに恩師渡辺厳一先生の御指導煘謝し京守.

\section{文献}

1) WATANABE, G. : Acta Medica et Biologica, $10: 1$, (1962). 2) JOSLIN, E.P., H.F. ROOT, P. WHITE and A. MARBLE : Treatment of Diabetes Mellitus, 10th ed., Lea\& Febriger, Philadelphia, (1959). $\quad 3$ 3) DRISGOLL, S.G., L. BENIRSGHKE and G.W. GURTIS : Am. J. Dis. Child, 100 : 818, $(1960$ 4) HOET, J.J., A. GOMMERS and J.P. HOET : The Third Congress of International Diabetes Federation, Düsseldolf, July, 21-25th, (1958). 5) WATANABE, G. and T. H. INGALLS : Diabetes, $12: 66$, (1963). $\quad$ 6) KALTER, H. and J. WARKANY : Physiol. Rev., $39: 69$, (1959). $\quad$ 7) SOMOGYI, M. : J. Biol. Chem., $160: 61,(1945) . \quad$ 8) INGALLS, T.H., F.J. GURLEY and R.A. PRINDLE : New Engl. J. Med., $247:$ 758, (1952). 9) INGALLS, T.H. and F.J. CURLEY : New Engl. J. Med., $256: 1035$, (1957). 10 ) FRASER, F.C., B.E. 
WALKER and D.G. TRASLER : Pediatrics, $19: 782$, (1957).

11) DURAISWAMI, P.K. : Brit. Med. J., II : 384, (1950). $\quad$ 12) LIGHTENSTEIN, H., G.M. GUEST and J. WARKANY : Proc. Soc. Exper. Biol. \& Med., $78: 398,(1951) . \quad 13)$ INGALLS, T.H. and F.J. CURLEY : Unpublished Experiments. 14) WICKES, I.G. : Brit. Med. J., II : 1029, (1954). 15) DANOWSKI, T.S. : Diabetes Mellitus, 271, Williams \& Wilkins Co. Baltimore, (1957). 16) LUKENS, F.D.W. : Physiol. Rev., 28 : 304, (1948). 